\title{
Genetic, abiotic and social influences on sex differentiation in cichlid fishes and the evolution of sequential hermaphroditism
}

Ronald George Oldfield

Museum of Zoology, University of Michigan, Ann Arbor, MI, USA

\begin{abstract}
Genetic and environmental factors may interact to control sex determination in fishes. A common pattern of initial female differentiation and subsequent male transformation before maturation in non-hermaphroditic fishes and after maturation in sequentially hermaphroditic fishes has suggested that changes in developmental timing may be responsible for the evolution of various expressions of sexual lability. Sequential hermaphroditism is rare in freshwater fishes, but investigators report degrees of sexual lability at four distinct life stages in cichlid fishes. Some cichlids undergo genetic sex determination and are not labile. Lability at the larval stage allows temperature or $\mathrm{pH}$ to determine sex. Social interactions apparently determine sex at the juvenile stage in the Midas cichlid (Amphilophus citrinellus). Most reports of post-maturational sex change in cichlids are anecdotal or unsubstantiated. The common occurrence of samesex spawning suggests that many species are incapable of sex change. Sequential hermaphroditism is concluded not to be typical, except for the checkerboard cichlid (Crenicara punctulata), which regularly undergoes functional female-to-male transformation. Expression of sexual lability at four life stages in one family of fishes corroborates a role for developmental timing in the evolution of sequential hermaphroditism as well as environmentally controlled sex determination. The broad phylogenetic distribution of sexual lability in cichlids indicates that processes capable of producing sex change are generally present. The rarity of sequential hermaphroditism in cichlids and possibly other freshwater fishes is likely due to unpredictability of food and therefore potential mate distributions compared with coral reef habitats.
\end{abstract}

Keywords cichlid, environmental sex determination, hermaphroditism, sex-change, sexual lability

\author{
Correspondence: \\ Ronald George \\ Oldfield, Museum of \\ Zoology, University of \\ Michigan, Ann Arbor, \\ MI 48109, USA \\ Tel.: + 7346472192 \\ Fax: + 7347634080 \\ E-mail: roldfiel@ \\ umich.edu \\ Received 13 Oct 2004 \\ Accepted 9 May 2005
}

$\begin{array}{ll}\text { Introduction } & 94 \\ \text { Genetic Sex Determination } & 96 \\ \text { Lability at the larval stage: environmental sex determination } & 97 \\ \text { Lability at the juvenile stage: social control of sex determination } & 99 \\ \text { Lability at the adult stage: sequential hermaphroditism } & 100 \\ \text { Absence of sex-change in same-sex pairs } & 102 \\ \text { Discussion } & 104 \\ \text { Acknowledgements } & 107 \\ \text { References } & 107\end{array}$ 


\section{Introduction}

Genetic factors control sex determination in most fishes. However, extrinsic factors also influence sex in many species. Before maturity, abiotic factors such as temperature and $\mathrm{pH}$ may determine sex. After maturity, behavioural interactions may initiate a functional sex change, i.e. the sequential hermaphroditism observed in many coral reef fishes (Fishelson 1970; Robertson 1972; Fricke and Fricke 1977). In most of these species individuals mature as an initial sex and later transform into the terminal sex. In protogynous species, individuals mature as females and then transform into males. In protandric species, males are the initial sex and females the terminal sex.

The size-advantage model has been proposed to explain why sequential hermaphroditism may be advantageous (Ghiselin 1969). According to this model, an individual may change sex if it would result in an increase in its expected future fitness. Males are generally capable of producing similar amounts of gametes regardless of body size. Eggs are much larger than sperm, and fecundity in females increases with body size. In group-spawning species males of all body sizes have similar chances of fertilizing eggs. When young and small an individual could maximize reproduction by functioning as a male. As the male grows it may reach a point when its future reproductive potential as a female would exceed that expected if it continued to reproduce as a male. It would then maximize reproduction by undergoing protandrous sex change. If ecological conditions allow the largest males to defend harems, male reproductive potential may increase exponentially with body size, and protogynous sex change would maximize fitness (Warner 1975).

A change in developmental timing has been proposed as a mechanism involved in the evolution of sequential hermaphroditism. In some gonochoristic fishes, where individuals are only functional as one sex in their lifetimes, individuals differentiate directly as a male or female early in development. However, in many gonochores all individuals initially differentiate as females, but early in development some are diverted, presumably by genetic factors, to differentiate as males (Uchida et al. 2002). Oocytes often remain in the gonads after these rudimentary hermaphrodites mature as males. This led to the idea that sequential hermaphroditism may evolve from a post-displacement of this pre-maturational sex change into adulthood (reviewed by Atz 1964; Shapiro 1987; Francis 1992).

Large scale variation in the timing of sex-change supports the theory that sequential hermaphroditism evolves by changes in developmental timing. Some populations of sequential hermaphrodites contain exceptional individuals that mature as the terminal sex and do not undergo adult sex-changes (Robertson and Warner 1978). However, histological evidence in the protogynous bluehead wrasse (Thalassoma bifasciatum, Labridae) has shown that even 'primary males' initially differentiate as females but change sex before maturity (Shapiro and Rasotto 1993). In addition, the juveniles of many gonochoristic fishes that are closely related to sequential hermaphrodites possess gonads that contain both male and female structures, called intersexual gonads, suggesting precocious sex change (Smith and Young 1966; Buxton and Garrett 1990; Baca Hovey et al. 2002). Fishes that have sex determined before maturity by environmental factors provide an example of another variant in timing of gonad development. This suggests that a prolonged period of gonad differentiation may result in different expressions of sexual lability depending on the life-stage at which it terminates.

The initial female differentiation observed in rudimentary hermaphrodites led to the idea that femaleness may generally be the default or initial sex in fishes (Shapiro 1992). Even protandric hermaphrodites do not initially differentiate as males. The gonads of juvenile dusky anemonefish (Amphiprion melanopus, Pomacentridae) contain primarily female tissue. Testicular tissue becomes more prominent when fish mature as males, but then regresses when they transform into females (Shapiro 1992; Godwin 1994). Shapiro (1992) noted similar findings in three other Amphiprion species, and also in Sparus aurata (Sparidae) that were serially sampled from captive groups. Juveniles of protandric creediids also have intersex gonads (Langston 2004). The gonads in these species only become mostly male upon maturation. Therefore, maleness in protandric species is a transitional stage rather than the initial sex, and patterns of sex differentiation as seemingly different as protogyny and protandry share a general female-to-male pattern.

Although hermaphroditic species are common on coral reefs, they are rare in freshwaters. There are 
no freshwater fishes that have been well studied and generally accepted to be sequential hermaphrodites. No explanations have been proposed to account for this absence. Possible clues may lie in the cichlid fishes.

The Cichlidae has often been considered sister to one of two families, Pomacentridae and Labridae (Stiassny and Jensen 1987; Streelman and Karl 1997), that contain the most well-known marine fishes that undergo sex-change. These relationships have recently been questioned; an alternative phylogeny places Cichlidae sister to a group containing many hermaphrodite-containing perciform lineages (Sparks and Smith 2004). Cichlids are extremely speciose and diverse, and have evolved a broad range of reproductive strategies that include substrate-spawning and mouthbrooding (Barlow 2001); uniparental (Fryer and Iles 1972), biparental (Barlow 1976), communal (Ward and Wyman 1977; Taborski 1984), and interspecies (McKaye 1977) brood care; and mating systems that include monogamy, polygamy, and sneaking strategies (tilapia species discussed in Oliveira and Canario 2001).

Although reports of sequential hermaphroditism are uncommon in cichlids, there are more reports of various expressions of sexual lability in this group than in other groups of freshwater fishes (Table 1). However, Kallman (1984) found reports by four authors that had claimed to observe sexchange in poeciliids to be inconclusive or unsubstantiated despite the fact that they had been cited often. I will evaluate published reports of sexual lability in cichlids. Analysis of these reports may elucidate mechanistic and phylogenetic patterns within the group that may lead to a better understanding of the processes involved in the evolution of sexual lability and the scarcity of hermaphroditism in cichlids and other freshwater fishes.

As genetic sex determination (GSD) is generally considered to be the ancestral mechanism of sex determination in fishes (Smith 1975), it needs to be understood so as to effectively conceptualize

Table 1 Cichlids reported to undergo genetic sex determination (GSD), environmental sex determination (temp. or $\mathrm{pH}$ ), socially controlled sex determination (SSD, before maturation) and sequentiel hermaphroditism (SH, post-maturation), and same-sex mating (S-S) without subsequent sex change that indicates an absence of sex change ability

\begin{tabular}{|c|c|c|c|c|c|c|c|}
\hline Range & Species & GSD & Temp. & $\mathrm{pH}$ & SSD & $\mathrm{SH}$ & S-S \\
\hline India & Etroplus maculatus & & & & & $\mathrm{X}^{1}$ & $0^{2}$ \\
\hline \multirow[t]{10}{*}{ Africa } & Oreochromis niloticus & $x^{3}$ & $x^{4}$ & & & & \\
\hline & Oreochromis aureus & $x^{5}$ & $x^{6}$ & & & & \\
\hline & Oreochromis mossambicus & $\mathrm{X}^{7}$ & $x^{8}$ & & & & $0^{9}$ \\
\hline & Sarotherodon melanotheron & & & & & $x^{1}$ & $0^{10}$ \\
\hline & Astatotilapia burtoni & & & & $0^{11}$ & & \\
\hline & Hemichromis bimaculatus & & & & & & $0^{12}$ \\
\hline & Pelvicachromis spp. $(n=3)$ & & & $X^{13,14}$ & & $X^{13}$ & \\
\hline & Pseudocrenilabrus multicolor & $X^{15}$ & $0^{16}$ & $0^{16}$ & & & \\
\hline & Pseudotropheus lombardoi & & & & & $0^{17}$ & \\
\hline & Tramitichromis intermedius & & & & & $0^{18}$ & \\
\hline South & 'Cichlasoma' octofasciatum & & & & & & $0^{19}$ \\
\hline \multirow[t]{3}{*}{ America } & Apistogramma spp. $(n=37)$ & & $X, 0^{14,16}$ & $X, 0^{14,16}$ & & & \\
\hline & Cichlasoma portelegrense & & & & & $x^{20}$ & \\
\hline & Crenicara punctulata & & & & & $x^{21}$ & \\
\hline Central & Archocentrus nigrofasciatus & $x^{22}$ & & & $x^{23}$ & & $0^{24}$ \\
\hline America & Amphilophus citrinellus & & & & $x^{25}$ & & \\
\hline
\end{tabular}

' $X$ ', presence of sex differentiation, ' 0 ', absence.

Superscript numbers indicate references.

1: Barlow (2000); 2: Barlow (1970); 3: Jalabert et al. (1974), Carrasco et al. (1999); Lee et al. (2003); 4: Baroiller et al. (1995, 1996); Abucay et al. (1999); 5: Guerrero (1975); 6: Desprez and Melard (1998); 7: Clemens and Inslee (1968); 8: Wang and Tsai (2000); 9: Oliveira and Canario (2001); 10: Aronson (1948, 1951); 11: R. D. Fernald, personnal communication; 12: Greenberg (1961); 13: Heiligenberg (1965); 14: Rubin (1985); 15: Hackmann and Reinboth (1974); 16: Römer and Beisenherz (1996); 17: Naish and Ribbink (1990); 18: Harnish (2004); 19: Seitz (1942); 20: Polder (1971); 21: Ohm (1978, 1980); Zupanc (1985); Carruth (2000); 22: George and Pandian (1996); 23: Williams (1972); 24: R.G. Oldfield unpublished data; 25: Francis and Barlow (1993). 
how extrinsic factors could interact with genes to control phenotypic sex. The next section provides an overview of our current understanding of how genetic factors influence sex in cichlids. The following three sections will then review in detail reports of sexual lability in cichlids at successive life stages and identify patterns of initial female development. Reports of same-sex mating without subsequent sex change will be reviewed and interpreted to indicate an absence of lability at the adult stage. These reports will then be evaluated.

Evidence of lability at multiple life stages will support the hypothesis that various expressions of sexual lability, including sequential hermaphroditism, may evolve by ontogenetic extension in the critical period of gonad differentiation (Fig. 1). In a phylogenetic context, a concentration of labile species in one clade within Cichlidae would indicate than an evolutionary emergence or loss of the developmental process capable of producing sequential hermaphroditism could account for its rarity. A broad distribution of labile species in the cichlid cladogram would indicate that a developmental process capable of producing sequential hermaphroditism is generally present in cichlids, but that some aspect of coral reef environments that makes sequential hermaphroditism adaptive for labrids and pomacentrids is absent in freshwater environments.

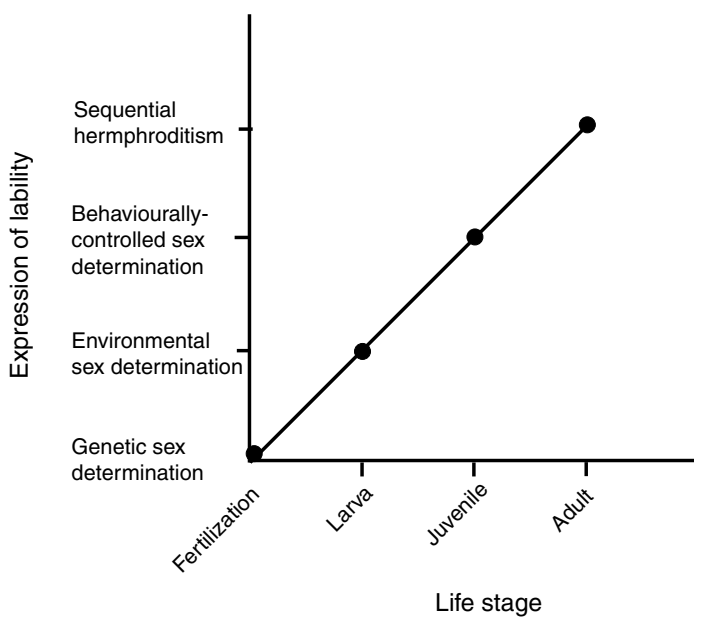

Figure 1 Continuum of various expressions of sexual lability. A different expression may result depending on the life stage during which the critical period of gonad differentiation ends.

\section{Genetic sex determination}

Most fishes do not have heteromorphic sex chromosomes (Devlin and Nagahama 2002). Thompson (1976) examined karyotypes of 47 cichlids, concentrating on neotropical species, and found no differences in chromosome shape between the sexes. A later review concluded that there are no morphologically distinguishable sex chromosomes published for any cichlids, perhaps with the exception of Geophagus brasiliensis (Kornfield 1984). A region of one chromosome that is non-homologous between males and females has been identified in the Nile tilapia cichlid (Oreochromis niloticus) by transmission electron microscopy (TEM) analysis of the synaptonemal complex (Carrasco et al. 1999). Therefore, sex chromosomes may exist in cichlids although they are not morphologically apparent using traditional observation techniques.

Sex-influencing genes have been identified in some fishes. A male-determining gene, named DMY, has been recently identified and sequenced in a strain of medaka (Oryzias latipes, Adrianichthyidae), although this species has no visually apparent sex chromosomes (Matsuda et al. 2002; Nanda et al. 2002). DMY evolved recently as a duplicate of the autosomal gene, DMRT1 (Zhang 2004), which had been suspected to cause male differentiation in the rainbow trout (Oncorhynchus mykiss, Salmonidae; Marchand et al. 2002). A DNA fragment that is a male sex-linked marker has been isolated for the three-spined stickleback (Gasterosteus aculeatus, Gasterosteidae) using a restricted fragment length polymorphism method. However, no markers could be found for nine-spined (Pungitius pungitius, Gasterosteidae) or 15-spined sticklebacks (Spinachia spinachia, Gasterosteidae; Griffiths et al. 2000). A male-specific DNA probe was isolated from Chinook salmon (Oncorhynchus tshawytscha, Salmonidae) by the use of a subtractive hybridization technique (Devlin et al. 1991). Molecular evidence for a sexdetermining gene has also been found in a cichlid. Offspring of three mating pairs of Oreochromis niloticus were analysed genetically by bulked segregant analysis for evidence of a male sex-determining region (Lee et al. 2003). The method identified a region of DNA that predicted phenotypic sex in more than $95 \%$ of progeny from two of the pairs. However, it was ineffective in the third.

By progeny testing artificially sex-reversed fish, some cichlids have been found to undergo GSD in a manner indicative of a heterogametic system. Gen- 
etic sex can be overridden in many fish species by early treatment with exogenous hormones (reviewed by Hunter and Donaldson 1983; Pandian and Koteeswaran 1999). For example, evidence for male heterogamety (XY/XX) may be obtained after larva are masculinized with an androgen (typically $17 \boldsymbol{\alpha}$-methyltestosterone). If an $\mathrm{XY} / \mathrm{XX}$ sex-determining mechanism is present, half of the resulting males will be normal (XY), and the other half will be sex-reversed females (XX). When these treated males are then bred to normal females (XX), half of the pairs should yield broods in which all progeny differentiate as females. The males of those pairs must have been sex-reversed genetic females (XX), and males must be the heterogametic sex. A similar method can be used to detect female heterogamety (ZZ/ZW).

Aquaculture researchers have extensively studied sex determination in tilapia. Monosex cultures increase production by preventing mating so that the fish allocate higher proportions of energy towards growth. Interestingly, Oreochromis niloticus has been demonstrated to have male heterogamety (XY/XX; Jalabert et al. 1974), and a congeneric species, the blue tilapia (Oreochromis aureus), female heterogemety (ZZ/ZW; Guerrero 1975). The Mossambique tilapia (Oreochromis mossambicus) has been found to have heterogametic males (Clemens and Inslee 1968), although a conspecific strain appears to be female heterogametic (Hickling 1960). The non-tilapiine Egyptian mouthbrooder (Pseudocrenilabrus multicolor) and the neotropical convict cichlid (Archocentrus nigrofasciatus) have both been found to have sex determined by XY/XX genetic mechanisms (Hackmann and Reinboth 1974; George and Pandian 1996). Although sexreversed fish usually yield monosex broods, there are often a few anomalous individuals that do not differentiate as expected. When George and Pandian (1996) mated genetically sex-reversed XX A. nigrofasciatus males with normal XX females they observed broods that contained nearly all females and also a few males.

Inconsistencies in otherwise straightforward sex determination mechanisms may be results of the multilocus, multichromosomal nature of sex determination mechanisms in fishes. Kallman (1984) found $\mathrm{W}, \mathrm{X}$, and $\mathrm{Y}$ sex chromosomes in most populations of the platyfish, Xiphophorus maculatus (Poeciliidae). In this system chromosome combinations of WY, WX and XX result in females and $X Y$ and YY result in males. These chromosomes share some of the same genes and are morphologically indistinguishable. YY males are possible because Y has not accumulated deleterious mutations typical in $\mathrm{Y}$ chromosome evolution (Liu et al. 2004). There are additional male-promoting genes on all of these sex chromosomes, but they are not usually expressed. There are also a number of sex-influencing autosomal genes that can interact with the primary sex determining genes. Autosomal genes have been proposed to account for the many reports of exceptional individuals that contradict their genetic sex, and they have been shown to be heritable. The absence of absolute dominance by any one sex determining gene or allele may be what allows environmental factors to have such a profound effect on sex differentiation in some species.

\section{Lability at the larval stage: environmental sex determination}

Abiotic environmentally controlled sex determination (ESD) occurs when extrinsic factors such as $\mathrm{pH}$ and temperature influence the direction of sex differentiation. The most well understood case of ESD in a fish is that of the Atlantic silverside (Menidia menidia, Atherinidae), on the Atlantic coast of North America (Conover and Heins 1987). Populations of this species that occur at higher latitudes experience short growing seasons. These populations undergo GSD. However, populations at lower latitudes experience longer growing seasons and offspring produced early in the season usually grow larger in their first year than those produced later. Large body size is more important to females than to males in this species, as fecundity increases with size in females but not in males. Larva of these lower latitude populations undergo temperature-controlled sex determination. Those produced earlier in the season experience colder initial temperatures than those produced later. Cold temperature predicts large body size and causes female differentiation that maximizes the future fitness of exposed individuals.

Environmental sex determination has been observed in cichlids in the laboratory. Heiligenberg (1965) described skewed sex ratios in Pelvicachromis pulcher that were correlated with $\mathrm{pH}$. In broods of 50-80 fish, acidic water ( $\mathrm{pH} 4-5)$ yielded 90\% males and neutral water $(\mathrm{pH} 7.0$ ) 90\% females. Rubin (1985) found three species of Pelvicachromis and two species of Apistogramma to differentiate as males when in acidic water $(\mathrm{pH}<6.0)$ and females in neutral water $(\mathrm{pH} 7.0)$. It is interesting to note 
that the green swordtail (Xiphophorus helleri, Poeciliidae) yielded similar results. Römer and Beisenherz (1996) investigated the effects of temperature and $\mathrm{pH}$ in 37 species of Apistogramma, Pseudocrenilabrus multicolor, and another poeciliid, Limia melanogaster. The authors inferred sex from secondary sexual characteristics. Temperature significantly affected sex ratio in 33 species of Apistogramma. Generally, low temperature $\left(23{ }^{\circ} \mathrm{C}\right)$ produced females, high temperature $\left(29^{\circ} \mathrm{C}\right)$ males, and intermediate temperature $\left(26^{\circ} \mathrm{C}\right)$ a $1: 1$ sex ratio. Limia melanogaster showed a similar sensitivity. Sex in A. caetei was affected by $\mathrm{pH}$, but not temperature. Temperature and $\mathrm{pH}$ did not affect sex determination in P. multicolor. Although the labile periods are the same for both hormones and temperature in Oreochromis niloticus (see below), sex determination in $P$. multicolor is sensitive to extrinsic hormones (Hackmann and Reinboth 1974) but not temperature or $\mathrm{pH}$.

Temperature-controlled sex determination has also been identified in tilapia. Generally, when larva are subjected to higher temperatures during the period of exogenous steroid sensitivity, sex ratios are skewed towards males. Wang and Tsai (2000) investigated the effects of temperature on young Oreochromis mossambicus. After 5 days of exposure at the treatment temperatures, groups were brought to $24{ }^{\circ} \mathrm{C}$, raised until they were 150 days old, and then sexed. Method of sexing was not described. Fish exposed to a cool temperature $\left(20^{\circ} \mathrm{C}\right)$, either between days 1 and 5 or 6-10 post-hatching, yielded significantly higher ratios of females than did higher temperatures. Fish exposed to warmer temperatures (either $28{ }^{\circ}$ or $32{ }^{\circ} \mathrm{C}$ ) between the ages of 11 and 15 days differentiated significantly more as males. The observed sex ratios are not the result of differential mortality, as survival rate was between $95 \%$ and $98 \%$ in all groups. Intermediate temperatures yielded balanced sex ratios. The observed female-before-male sensitivity is consistent with a pattern of initial female development (Shapiro 1992).

A masculinizing effect of high temperature has also been found in Oreochromis aureus (Desprez and Melard 1998). Treatment temperature began at 9 days post-spawning and fish were sexed at 69 days. Nearly 100\% of the fish reared at high temperature $\left(34{ }^{\circ} \mathrm{C}\right)$ differentiated as males. Mean percentage of males in groups raised at an intermediate temperature $\left(27^{\circ} \mathrm{C}\right)$ was $63 \%$, not significantly different from a 1:1 sex ratio. Fish raised at low temperature $\left(21^{\circ} \mathrm{C}\right)$ experienced very high mortalities (mean survival $=43 \%$ ). Survival was also low in the control (73\%) and high temperature $(82 \%)$ treatments. Most of the surviving fish from the low temperature treatments were undifferentiated at 69 days, although some had differentiated as females. Fifty individuals from one low temperature group were raised for an additional 60 days and sexed. At that time the ratio had evened out (46\% male). This female-before-male differentiation supports a pattern of primacy of female development.

Baras et al. (2000) observed sex differentiation in groups of Oreochromis aureus raised under temperatures that fluctuated daily from 27 to $35^{\circ} \mathrm{C}$, in order to better approximate natural conditions. As was found previously (Desprez and Melard 1998), they observed even sex ratios (0.75-0.82:1) under constant neutral temperature of $27^{\circ} \mathrm{C}$, and malebiased sex ratios (7.33-19:1) at high temperature $\left(35^{\circ} \mathrm{C}\right)$. Sex ratios of groups raised under fluctuating conditions were male-biased (2.33-11.5:1), although not as strongly as the constant warm treatment. Intersex gonads were observed at 46 days in some individuals in the high temperature and fluctuating treatments. They were mostly differentiated as testes, with a few oogonia. However, all fish sexed at 90 days were completely differentiated as one or the other sex. This suggests that intersex individuals were genetic females whose sex was reversed by the temperature treatments.

Baroiller et al. $(1995,1996)$ tested the masculinizing effect of high temperatures in Oreochromis niloticus. Each of 10 progenies from different breeding pairs was divided into two to seven groups, each group contained an average of 144 fish. Fish were subjected to either the control $\left(27-29^{\circ} \mathrm{C}\right)$ or treatment $\left(34-36^{\circ} \mathrm{C}\right)$ temperatures over the typical androgen sensitive period, beginning 9-13 days after fertilization and lasting 21 days. The first histological signs of ovarian differentiation begin during this period (Nakamura et al. 1998). Larva were removed from brooding mothers 7-9 days after fertilization and subjected to control temperature before and after treatment. After 3 months, over 100 fish in each group were sexed by the aceto-carmine squash method (Guerrero and Shelton 1974). Fish generally exhibited significantly higher proportions of males at higher temperatures (up to $81 \%$ at $36{ }^{\circ} \mathrm{C}$ ). Survival was similar in control $(76.9 \%)$ and treatment $(71.4 \%)$ groups. 
Duration of treatment was tested in other groups by subjecting them to high temperatures for periods of 10-60 days. Ten days was significant to induce masculinization, and longer treatments did not increase male proportions. Age at treatment was also tested in other groups by beginning treatment at 7-21 days post-fertilization. High temperature caused masculinization in treatments begun 13 days post-fertilization or earlier, but not in treatments beginning 15-21 days post-fertilization, demonstrating a close association between period of sensitivity to temperature and the period of hormone sensitivity.

In order to verify that some males observed in high temperature treatments were sex reversed XX females, the sex ratios of progenies of temperaturetreated males were examined. One 10-day-old brood was divided into two groups and exposed to either normal $\left(27^{\circ} \mathrm{C}\right)$ or high $\left(36^{\circ} \mathrm{C}\right)$ temperatures for 21 days, which yielded $45.8 \%$ and $79.2 \%$ males respectively. Resulting males were then raised to maturity and mated with normal females. All broods derived from 15 control males yielded balanced sex ratios. However, four of 10 broods derived from the high temperature treated males contained all females. This shows that some of the males observed in the high temperature treatments were genetic females whose sex was reversed by high temperature. Twenty-three pairs derived from these genetic females were then formed and their offspring raised at control and high temperature treatments. All of the broods showed higher frequencies of male differentiation at higher temperatures. Six pairs produced all female offspring at control temperatures and high proportions of males at high temperatures. Surprisingly, some of these supposed genetic female pairs yielded balanced sex ratios at control temperatures. Baroiller et al. (1995) concluded that temperature and sex chromosomes govern sex ratios in Oreochromis niloticus and that sex differentiation is irreversible after 15 days post-fertilization, but labile before the onset of histological evidence of gonadal differentiation. The masculinizing effects of high temperature in this species have also been observed by other investigators (Abucay et al. 1999).

\section{Lability at the juvenile stage: social control of sex determination}

Social control of sex determination might occur if the critical period of gonad lability was prolonged into the juvenile stage, when behavioural interactions before maturity could influence the direction of sex differentiation. A version of this hypothesis was originally proposed by Williams (1972) for the convict cichlid. In adults of this species, males are larger than females. Williams divided each of two broods into experimental groups according to relative body size within their original brood. If large body size was the result of maleness, then experimental groups that were composed of initially large fish would all differentiate as males, and those that were initially small all as females. After fish reached maturity, Williams was unable to observe significant differences in sex ratio among the groups. It is possible that individual fish assessed their body size relative to other members in their group, and differentiated into males if they were relatively large, and females if relatively small. Williams did not provide the size-sex distributions within the experimental lots, so it is unknown if there was an association between size and sex at the time of sampling. In addition, the very high levels of mortality observed could have obscured disproportionate mortality between the sexes.

Francis (1984, 1990) and Francis and Barlow (1993) have since provided evidence for socially controlled sex determination in two teleost fish species. Initially, Francis (1984) described social control of sex determination in the paradise fish (Macropodus opercularis, Anabantidae). Ratios of males in captive populations were found to be inversely correlated with stocking density, and individuals usually developed as males when raised in solitude. In addition, lines selected for dominance yielded high ratios of males and those selected for subordinance high ratios of females.

Francis (1990) and Francis and Barlow (1993) then showed that relative body size as a juvenile determines sex in the Midas cichlid, Amphilophus citrinellus. Captive groups of this species exhibit a hierarchy effect during growth (Brown 1957). Large individuals in a social group suppress the growth of smaller subordinates through behavioural interactions. Behavioural interactions can affect somatic and gonadal development in both gonochoristic and hermaphroditic fishes. An increase in growth has been documented to co-occur with sex change in the protogynous saddleback wrasse (Thalassoma duperrey, Labridae; Ross 1987), and is suspected but not quantified in Pseudanthias squamipinnis (Serranidae; Shapiro 1979) and Amphiprion akallopsis (Pomacentridae; Fricke 
and Fricke 1977). As in Archocentrus nigrofasciatus, adult male $A$. citrinellus are known to be larger than females, and a captive social group had been shown to maintain a stable size hierarchy from the juvenile stage to adulthood (Francis 1990).

A 6-month-old brood of $A$. citrinellus was separated into two experimental groups based on size: those above the median and those below. If size and sex were only controlled by genetic factors, the group containing the smaller individuals would be expected to develop into females, and the group of larger fish into males. The two groups were raised for another 6 months and then killed. Free of the aggressive behaviours of the larger individuals, fish in the 'small' group experienced growth compensation (see Ali et al. 2003). Mean body sizes in the two groups were found to be nearly equal. In addition, each group contained about a 1:1 ratio of females to males, with the females being the smaller, and males being the larger individuals of each group. Francis and Barlow (1993) reasoned that, because of the stable size hierarchy, relatively large size as a juvenile predicts large size as an adult, and large fish could maximize fitness by differentiating as males, as competition for breeding sites in the natural habitat is intense and large body size helps males effectively guard the brood site while females tend the offspring. The authors argued that the fish were interpreting their relative size via aggressive interactions, but did not present behavioural data. They posited that all Midas cichlids may initially differentiate along a default female trajectory, and that being subordinate to conspecifics repressed the prematurational transformation from female to male.

Francis and Barlow (1993) were unsure if the sexcontrolling process they observed was a prematurational sex change or social control of initial sex determination and they questioned the distinction between the two concepts. Francis (1990) stated that 12-week-old Midas cichlid gonads are undifferentiated and cannot be sexed histologically. Although the European sea bass (Dicentrarchus labrax, Moronidae) remains sexually undifferentiated until 9 months of age (discussed in Carrillo et al. 1995), it is unlikely that Midas cichlids delay differentiation for 12 weeks. Other cichlids begin gonad differentiation much sooner. In Oreochromis niloticus, differences between testes and ovaries can be distinguished as early as 2023 days after hatching (Nakamura et al. 1998). Similarly, female Cichlasoma dimerus begin ovarian differentiation when 15 days old (Meijide 2005).
Like the closely related Archocentrus nigrofasciatus, $A$. citrinellus may also have a genetic component to sex determination (George and Pandian 1996). If so, it is likely that it begins differentiation at a very early age according to its genotype. Later, social factors either support or compete with the genetic influence, as temperature does in Oreochromis niloticus, and the fish perform pre-maturational sex changes.

Rhodes and Francis later examined sex determination in Astatotilapia burtoni (Cichlidae). In this species, there was no indication that sex was determined by social conditions (R.D. Fernald, personal communication).

\section{Lability at the adult stage: sequential hermaphroditism}

Several authors have reported anecdotes or investigations of adult sex-change in cichlids. Barlow (2000) once separated females from males of black chinned tilapia (Sarotherodon melanotheron) and males later appeared in the group of females. On another occasion, he similarly separated orange chromides (Etroplus maculatus) by sex. Females would usually pair with each other and spawn, but the eggs were infertile. However, two E. maculatus that had both previously spawned with males produced a few eggs that hatched (Barlow 2000).

In a short communication, Heiligenberg (1965) mentioned two cases in which female Pelvicachromis pulcher changed into males. In one brood, five females changed into males, and in another case one female changed into a male. These notes were added while the paper was in press and no details were given. We do not know whether the females had been observed previously laying eggs, or if their gonads were examined histologically.

Histological examination has revealed intersex gonads in many African cichlids. Peters (1975) examined 65 ovaries and 63 testes of 14 species of haplochromine cichlids representing seven genera. All females had normal ovaries but the gonads of males of all species except Pseudotropheus livingstonii were ovotestes. Oocytes were distributed among the spermatogenic tissue, attached to the walls of the tubuli. They were much smaller than vitellogenic oocytes found in females and in some individuals had degenerated. There were no additional indications of sexual transformation in any of the fish examined. Behaviour was similar among fishes with differing amounts of oocytes. Within 
each species there was no difference in body size between sexes, which is often seen in sex-changing animals (Allsop and West 2003). A plausible explanation is that these fishes underwent prematurational sex changes and are rudimentary hermaphrodites.

Naish and Ribbink (1990) followed up on the possibility of sex change in haplochromines. Previous observations of wild Pseudotropheus lombardoi had found individuals that were coloured as males but were mouthbrooding, which is normally performed by females. In the laboratory, the authors isolated five groups, each containing one male and four to eight females in an attempt to stimulate sex change in one of the females. They left the group undisturbed for 1 month and then removed the male. Three tanks that contained four, six, and eight females served as controls. They also set up three groups that each contained five males and five females. After 1 month they removed the females in order to stimulate protandric sex change. They did not observe any sex changes. After 2 months one territorial female began to exhibit to male coloration, but upon dissection her gonads were found to be female. Like the haplochromines examined by Peters (1975), testes of adult males contained undeveloped oocytes. Of three juveniles, gonads of the smallest two had developing oocytes and the largest had both oocytes and spermatocytes. The authors concluded that males go through an intersexual juvenile period and that females are dichromatic. The evidence presented indicates that this species is not a sequential hermaphrodite.

Like many African cichlids, Tramitichromis intermedius is polygamous and fertilizations are limited to a few dominant males, a social system similar to those of some sex-changing coral reef fishes (e.g. Fishelson 1970; Robertson 1972). Harnish (2004) observed four groups of five previously spawned females for 16 weeks. No male colours or behaviours were observed. In addition, the gonads of 29 males and 30 females were examined histologically for evidence of sex change (Sadovy and Shapiro 1987), but none were found.

Neotropical cichlids have also been investigated for sex change. Loir et al. (1989) examined size distributions and gonad sections in Satanoperca aff. leucosticta. Males were found to have broader weight distributions than females; while some males were larger than females, many fell within the size range of the females. No overlap would suggest protogyny
(Sadovy and Shapiro 1987). Histological examination revealed all testes to be similar to those found by Peters (1975). They contained previtellogenic oocytes as well as male germ cells in all stages of spermatogenesis. This species is a rudimentary hermaphrodite.

In his detailed studies of reproduction in Cichlasoma portalegrense, Polder (1971) witnessed protogynous sex change. He described a reproductively functional mated pair in which the male became afflicted with some ailment, described as a 'defect of the swimbladder and respiratory system'. While the male was in this condition the female became dominant and grew until she was much larger than him. When Polder noticed secondary male characteristics (thick neck region and small genital papilla), he killed the animal and examined its gonads. Macroscopically and histologically they looked like normal functional testes, complete with masses of spermatozoa. The dorso-cranial end of the testes appeared as ovary walls, but contained no oocytes (Polder 1971).

In addition, Polder (1971) found a large group of captive $C$. portalegrense to be heavily biased toward males (60:2 after the removal of several mated pairs). Two more groups together contained 35 males, two females and three intersexes, with macroscopically visible male and female gonadal tissue. The ovarian tissue was situated in the anterior end of the gonad and the testicular tissue posterior. Histological sections revealed that all of the largest oocytes showed signs of degeneration, as did many of those of all sizes that were located near testicular tissue. There was no oviduct in the genital papilla, although the musculature was female. Sex reversal was attempted, but unsuccessful. Six recently functional females were placed into an aquarium together for 1 year and spawning did not occur. Polder also noted that he removed three male Archocentrus nigrofasciatus from an aquarium containing many individuals, and all had ovotestes containing various amounts of small oocytes. No details or micrographs were provided for A. nigrofasciatus.

The first studies to investigate sex change in the checkerboard cichlid, Crenicara punctulata, were conducted by Ohm $(1978,1980)$. The resulting publications were magazine articles that did not describe experimental methods or provide evidence of sex change. However, Zupanc (1985) provided a more complete account of Ohm's work. According to Zupanc (1985), Ohm established 30 groups each 
containing 4-10 young fish. At an age of 7-10 months the dominant fish in each group began to grow faster than the others. This fish differentiated as a male and the rest differentiated as females. If the male was removed then the most dominant female changed sex and began to mate normally with the remaining females, even if it had previously reproduced as a female. During the second year some females in each group began to differentiate into 'submales'. These fish were not the strongest males in each group and were not reproductively active, but did have male coloration. If the original alpha male was removed then these submales began to reproduce with the females in the group. Fish raised in isolation all went through female phases, but then changed into males at 710 months of age.

Zupanc (1985) provided some histological gonad sections from Ohm's work. A section from an alpha fish showed an intersex gonad with spermatocytes and sperm adjacent to two oocytes. Another section showed testes in a 3-year-old submale that had previously been a functional female. A gonad section from a 7-month-old subordinate female showed an ovary filled with oocytes in various stages of development.

Carruth (2000) gathered further evidence for sex change in $C$. punctulata. She initially maintained a group of 15 juveniles then divided it into four groups, three with four fish each and one with three fish. Initially, all had female coloration. In each group the dominant individual developed male coloration between 5 and 16 weeks. In order to establish that coloration is a reliable indicator of sex, one male, one dominant female, and two subordinate females were killed. Each had gonads consistent with external appearance. The remaining fish were placed in isolation. The three dominant females developed male traits, but the five submissive ones did not. After several weeks, one submissive female was housed with another. One individual developed secondary male traits. Histological examination revealed fish coloured as females to have ovaries. Some contained small amounts of undifferentiated tissue. Fish that had secondary male traits had well differentiated testes. Carruth concluded that the fish had changed sex. Unlike Ohm's sections, testes were found not to contain oocytes, even in males that were thought to have changed sex. The transformed males also had no gonadal lumens, which are often present in transformed males of other protogynous hermaph- rodites (Sadovy and Shapiro 1987). Mating did not occur.

\section{Absence of sex change in same-sex pairs}

In addition to failures to find sex change in studies where it was sought, evidence that some cichlids are incapable of sex change can be gathered from investigations of same-sex mating. Some true sequential hermaphrodites begin mating with conspecifics of the same sex prior to physically transforming to the opposite sex. Upon removal of the male in a polygynous group of cleaner wrasse (Labroides dimidiatus, Labridae) the largest female changes sex (Robertson 1972). Behavioural sexchange precedes morphological sex-change and takes place immediately after removal of the terminal sex individual in both $L$. dimidiatus and Thalassoma bifasciatum (Labridae; Robertson 1972; Warner and Swearer 1991). Several weeks are required to complete the transformation of the gonads, but a sex-change candidate female begins courting other females nearly immediately after male removal and performs the 'upward rush', typical in regular spawning, with other females. Nakashima et al. (2000) experimentally removed males from groups of $L$. dimidiatus and observed same-sex spawning behaviour in all dominant females. In most of these cases both spawning females released eggs. Upon the return of the removed males, male-role females resumed their previous subordinate roles and spawned with the males. The authors concluded that behavioural sex is changeable according to social status, independent of gonad condition, and that females will spawn with the largest member of their group, regardless of sex. Godwin et al. (1996) have shown that behavioural sex-change occurs in female T. bifasciatum even after their gonads had been removed.

Same-sex pairing in some cichlids without subsequent sex-change suggests that they possess the ability to change sex behaviourally, but lack the physiological or developmental capabilities required to complete the transformation. Male Oreochromis mossabicus often court other males (Oliveira and Canario 2001). Territorial males of this species have a dark nuptial coloration. Juveniles, females and non-territorial males have a pale colour and generally stay out of the territories. Oliveira and Canario (2001) found that 33\% of 618 total courtships by territorial males were directed towards other males, and that territorial males 
courted non-territorial males with a full courtship repertoire including tilting, signalling the nest, circling, and quivering. Courted males never had dark coloration typical of territorial males, and they frequently responded by behaving like females. They performed female behaviour including immobility, following male to the nest, and assuming a pivot position in the nest while being circled by the male. In three of 204 observed cases the courted male placed its mouth near the genital papilla of the male and, when it was quivering, performed a chewing motion typical of a female inhaling sperm to fertilize eggs.

Female-female courtship and spawning has been documented in many cichlids. However, whether or not one of the females behaved in a male role has been a matter of contention. Seitz's (1942) interpretation of female-female spawning in 'Cichlasoma' octofasciatum was that one layed eggs while the other 'skimmed' as a male would if attempting to fertilize them. However, both females displayed 'symbolic inferiorism' (female behaviour). Baerends and Baerends-van Roon (1950) reported spawning in three female jewelfish (Hemichromis bimaculatus) in a group of four and when one laid eggs another followed, skimming the eggs like a male.

Aronson (1948) observed spawning of isolated females and female-female pairs of Sarotherodon melanotheron. In this species courtship and spawning behaviours are similar between males and females. All reproductive behaviours are exhibited by both sexes. Even oviposition and fertilization are similar. However, there are differences between the sexes in amount of time spent performing specific behaviours. Females tail slap and build nests more than males. In courtship males pass over the nest more than females, but this is reversed at the onset of spawning. Each member's behaviour in a femalefemale pair is qualitatively similar, but one female performs behaviours in relative frequencies typical of a male (Aronson 1951). Therefore, one fish was considered to be in the male role. As would be expected from a heterosexual pair, the fish in the male role passed over the nest more during the time preceding spawning, and the female-role fish did so more often immediately before spawning. Immediately after spawning, the fish in the male role rubbed her genital papilla over the eggs as a male would do during fertilization (Aronson 1951). Visual cues alone stimulated spawning, and females allowed to view males or other females spawned at similar rates, which were much higher than spawning rates in isolated females (Aronson 1951).

Female-female pairing has also been documented in Etroplus maculatus. Barlow (1970) found that females evoke more courtship behaviour in both sexes than do males. Threesomes of females often form also. Barlow concluded that females normally do not form pairs because they evoke more attack in other females than do males, but pairs can form when 'motivation' to spawn exceeds aggression. When two males approach each other, their aggressive responses are greatly stimulated and their sexual responses are insufficiently aroused, therefore they do not form pairs.

Greenberg (1961) witnessed several femalefemale spawns in Hemichromis bimaculatus but concluded that females did not behave as males. In total, seven female-female pairs were observed spawning one or more times. Female-female pair formation occurred when one female blocked aggression from another by quivering or assuming the 'oestrous stand' - spreading the median fins and keeping the head raised while avoiding the attacks of the courting fish. Groups that contained even one small male yielded heterosexual pairs, suggesting that females prefer to mate with any male over a female. In some cases fertilized eggs of Cichlasoma portalegrense were substituted for the unfertilized eggs of the female-female pair. Sometimes the pair ate the foster eggs, but two pairs cared for the offspring. One of these pairs tended larva for 18 days before one female killed the other, after which the remaining female continued to raise them. The other pair brooded free-swimming larva for at least 21 days (final disposition not reported).

I have observed one female-female pairing in Archocentrus nigrofasciatus. In an attempt to stimulate sex change I set up three aquaria, each with four adult females and one overturned clay pot to serve as a spawning site. In one group, two of the females formed a pair bond and spawned in the pot. Unfertilized eggs appeared several times over a period of 6 months until I removed the fish. One of the females adopted a male pattern of parental care. It frequently drove away its tank mates and left the breeding site to feed, but frequently returned to the breeding site to guard the opening. The other remained at the breeding site most of the time fanning and cleaning the eggs, behaviours typical of a female (Itzkowitz et al. 2001).

Greenberg (1961) observed that neither female could be assigned a male role. Males seldom eat 
the eggs of their partners, but in many cases a female ate some of the eggs of her laying partner. In addition, both females of a pair alternated laying and fanning eggs in most cases, but males do not begin fanning until all eggs are laid. Each female appeared ready to spawn regardless of the actions of its partner. This agrees with Aronson (1951), who doubted the specific stimulating effect of a partner in female-female pairs, suspecting that isolated females might increase spawning frequency in the presence of shadows or other species.

Male Oreochromis mossambicus are apparently capable of assuming a female role and engaging in same-sex mating (Oliveira and Canario 2001). However, Greenberg (1961) and Barlow (2000) disagreed with claims like Aronson's (1948, 1951) that female cichlids mated in the male role. In substrate spawners males and females perform the same repertoire of behaviours. The sex roles differ only by time budget differences (which are variable). Itzkowitz et al. (2001) have described this quantitatively in the broodcare behaviours of Archocentrus nigrofasciatus. The absence of qualitatively different behaviours makes it difficult to demonstrate a change in sex role. However, the fact that females do form pairs and release gametes together does suggest that protogynous sex-change would occur if they possessed physiological pathways that could instruct the gonad to change sex, and the gonad was capable of such a transformation. It is unlikely that the species discussed in this section are normally able to change sex.

\section{Discussion}

Many species of coral reef fishes are sequential hermaphrodites (Devlin and Nagahama 2002). In contrast, no well-studied freshwater fishes have been found to regularly undergo post-maturational sex changes. It is possible that this difference stems from events in the evolutionary histories of various groups of freshwater fishes. Mechanisms capable of facilitating sex change may have been independently gained in coral reef ancestors or lost in freshwater ancestors. It is also possible that there is some fundamental characteristic of coral reef environments that favours sequential hermaphroditism that is absent in freshwater systems. While cichlids exhibit a paucity of hermaphroditic species compared with their close marine relatives, there are more reports of different expressions of sexual lability in cichlids than there are in other families of freshwater fishes.

Variation in the timing of gonad lability supports the hypothesis that sequential hermaphroditism may evolve by an ontogenetic extension in the critical period of gonad differentiation. Cichlid fishes exhibit four degrees of variation in timing of gonad lability. Some cichlids exhibit no sexual lability and have sex determined genetically. Sex-influencing genes probably occur in all cichlids, although they may be highly variable among species and even among individuals of a single species. These genes are likely distributed throughout the genome as in Xiphophorus maculatus (Kallman 1984). Sex chromosomes are hard to identify and appear not to be evolving in cichlids. There has been no chromosome degeneration typical in the evolution of sex chromosomes (Liu et al. 2004). Nevertheless, sex differentiation is canalized in many cichlid species.

In some species exogenous influences may interact with genetic influences early in ontogeny. During a short critical period, sex may be determined by extrinsic factors such as temperature or $\mathrm{pH}$. The corroboration of environmental sex determination in diverse cichlid species by independent investigators that employed well-designed experimental methods and thoroughly communicated results indicates that ESD is normal in many cichlids. These species express gonad lability at the larval stage.

Gonad lability at the juvenile stage, after behavioural interactions have developed, could result in social control of sex determination (Francis and Barlow 1993). Such individuals would not undergo functional sex changes and would be gonochores. This process has been proposed for two cichlids. An alternative explanation for the observations of Williams (1972) and Francis and Barlow (1993) is that the sexual size dimorphism present in adults begins to develop at the onset of sexual maturity. In introduced populations of the Mayan cichlid ('Cichlasoma' uropthalmus) there is no difference in body size between males and females at 1 year of age. In subsequent years, males grow faster than females, presumably because less energy is required for male gamete production (Faunce et al. 2002). Francis and Barlow (1993) discard this possibility in Amphilophus citrinellus because a stable size hierarchy was observed in a longitudinal study of a captive group of 12 fish that were individually tagged at an age of 10 weeks and followed for 18 months (Francis 1990). The statistical test used 
to demonstrate the significance of the stability of the size hierarchy was Kendall's concordance, and was computed for both weight $(W=0.912, P<.0001)$ and standard length $(W=0.914, P<0.0001)$. These values indicate that only three fish occupying adjacent ranks changed positions, or possibly two fish from close, but not adjacent ranks switched positions. This is a nearly stable hierarchy, but a small sample upon which to assume that other social groups will be stable as well. The evidence provided by Williams (1972) is not sufficient to conclude that social interactions control the direction of sex differentiation in Archocentrus nigrofasciatus. Data provided by Francis (1990) and Francis and Barlow (1993) are more convincing. Amphilophus citrinellus is concluded to undergo social control of sex determination, although the limited amount of evidence requires further study.

If the critical period of gonad differentiation reached into the adult stage, then social interactions could control sequential hermaphroditism. Most reports of sex change are from captive cichlids and are isolated cases, unreplicated, and unlikely to be species typical. In addition, the common occurrence of same-sex pairing in cichlids suggests that the behavioural components necessary for sex change are present, but gonad lability generally does not reach the adult stage.

The most convincing evidence of sequential hermaphroditism in a cichlid has been provided for Crenicara punctulata. However, Carruth (2000) concluded that individuals initially coloured as females were truly females based on gonad sections of only three fish (Carruth 2000). Heiligenberg (1965) may have made a similar assumption in Pelvicachromis pulcher. An alternative explanation is that juveniles, females, and non-reproductive males all lack male display coloration. Male Pseudotropheus lombardoi juveniles begin life looking like females and later develop male coloration (Naish and Ribbink 1990). In Astatotilapia burtoni and Oreochromis mossambicus, only territorial males exhibit display coloration. Juveniles, females and nonreproductive males all have drab coloration and shoal together above the territories of reproductive males (Fernald and Hirata 1977; Oliveira and Canario 2001). It is possible that Carruth's 'sexchanged' males may not have changed sex, but had maturation delayed through social interactions, as in Astatotilapia burtoni (Fraley and Fernald 1982; Davis and Fernald 1990) and other fishes (Bushman and Burns 1994; Kolluru and Reznick 1996), appearing as females until social conditions allowed them to mature as their genetically predetermined sex. Evidence provided by Zupanc (1985), and Carruth (2000) indicates that C. punctulata is a protogynous hermaphrodite, although more data would be desirable to draw a strong conclusion. Cichlids are thus concluded normally to be gonochores, with the exception of $C$. punctulata.

Aspects of the experimental methods in some of the studies reviewed may have reduced the possibility of observing sex change. Some authors either established all female groups (Polder 1971; Harnish 2004), or placed females in isolation (Carruth 2000), and waited for them to change sex. It is important to note that male removal, not absence, has been shown to be important in stimulating sexchange in the protogynous Pseudanthias squamipinnis (Shapiro 1979) and Thalassoma duperrey (Ross et al. 1983). Shapiro (1979) found that all-female groups of $P$. squamipinnis are common in nature and captivity. Ross et al. (1983) failed to observe sexchange in T. duperrey when females were placed into isolation. It is possible that male removal from established social groups of Cichlasoma portalegrense, Tramitichromis intermedius, and Crenicara punctulata would yield stronger sex-change results.

Descriptions of sex differentiation in cichlids corroborate a pattern of initial female development (Shapiro 1987, 1992). Males of gonochoristic haplochromines and Satanoperca aff. leucosticte appear to undergo pre-maturational protogynous sex changes as do many other gonochoristic fishes (Francis 1992). Studies on tilapia have indicated initial female differentiation, either by serial sampling or by susceptibility to temperature that is earlier for female than for male differentiation. While high temperatures induced male differentiation in all three species of tilapia examined, low temperatures induced female differentiation in only one of these. Apparently, it is easier for temperature to induce male differentiation in a genetic female than it is to induce female differentiation in a genetic male. Femaleness may generally be the default sex in cichlids, with male differentiation occurring when male-inducing factors, either genetic or environmental, are superimposed.

Cichlids exhibit great variability in timing of sex determination, with species expressing degrees of lability at four distinct life stages (Fig. 2). This finding supports the hypothesis that variability in developmental timing is involved in the evolution of sequential hermaphroditism, as well as other forms 
of sexual lability. Changes in relative time of appearance and rates of development of characters in a species relative to its ancestors have traditionally been observed in morphological features and have been termed heterochrony (Gould 1977). Heterochrony can be of two types. One type, paedomorphosis, is generally characterized by retention of juvenile traits to the adult life stage. The opposite, peramorphosis, is characterized by exaggerated development of some feature. In typical analyses, timing of development in homologous structures is described among a monophyletic group of species. A comparison can then be made between a focal species and its hypothesized ancestral state and any heterochronic patterns identified (Fink 1982). In fishes, gonochorism and GSD are generally considered to be ancestral (Smith 1975). Some of the gonochores discussed here express brief periods of lability at the larval stage. Sexual lability expressed later in ontogeny would exemplify retention of a larval trait (lability) into a subsequent life stage. Thus, the evolution of sequential hermaphroditism in fishes in general may be an example of paedomorphosis. As Crenicara punctulata is the only sequentially hermaphroditic cichlid, and its cichlid outgroups include species known to be gonochoristic, it too can be considered paedomorphic.

Instead of being a structure, sexual lability can be interpreted as physiological and developmental potential. As such, it poses exceptional difficulties when considering the specific mechanisms responsible for paedomorphosis (Alberch et al. 1979). Neoteny, progenesis and post-displacement are all candidate processes.

Some unsubstantiated reports of sequential hermaphroditism in cichlids are not species typical. If accurate, these may be examples of intraspecific paedomorphosis (Reilly et al. 1997). This interpretation is consistent with the co-occurrence of gonochorism and sequential hermaphroditism within single populations of many marine species (Smith and Young 1966; Robertson and Warner 1978; Warner and Robertson 1978; Baca Hovey et al. 2002).

Phylogenetic hypotheses are available for cichlid relationships and a composite phylogeny has been used to map the evolution of parental care behaviours (Goodwin et al. 1998). Phylogenetic analysis has recently been successful at mapping emergence and loss of hermaphroditism in the Creediidae (Langston 2004). The reports of sexual lability in cichlids reviewed here have been placed into a phylogenetic framework (Fig. 2). There are insufficient data to conclusively identify the evolutionary emergence of each case of sexual lability, but the cases are dispersed throughout the phylogeny and apparently do not represent one evolutionary transformation. Although the two cichlids that apparently have sex differentiation influenced by social factors (Amphilophus citrinellus and Crenicara punctulata) are both neotropical, the species concluded to undergo ESD represent various clades of both South American and African taxa.

If the developmental mechanism capable of producing sequential hermaphroditism is present throughout Cichlidae, but sequential hermaphroditism is very rare, some aspect of marine environments that favours sequential hermaphroditism must be absent from freshwater environments. Barlow (1993) contrasted the abundance of fishes that regularly maintain feeding territories in marine environments to their absence in freshwaters and attributed the difference to permanence of food

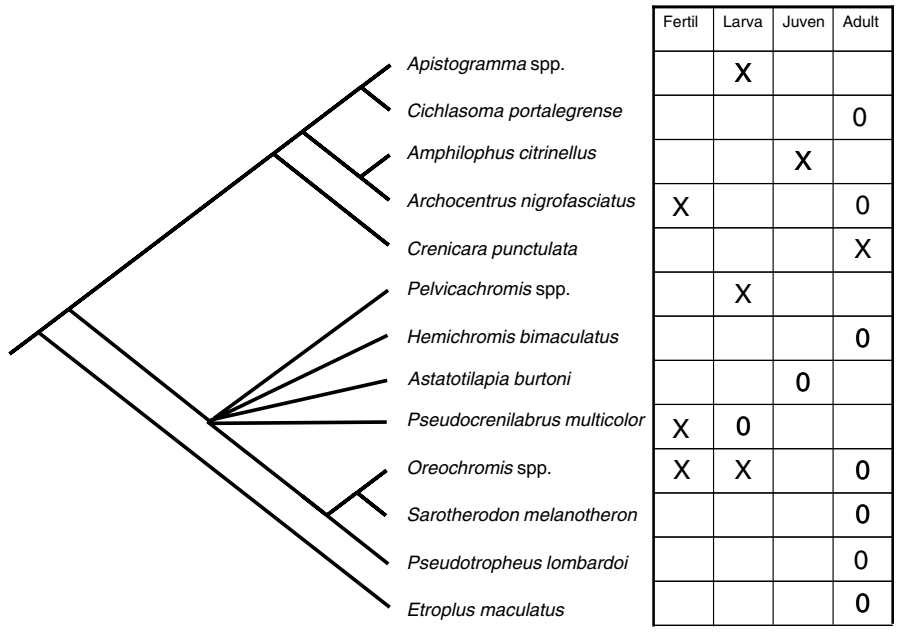

Figure 2 Phylogenetic relationships of cichlid taxa discussed in the text as hypothesized by Goodwin et al. (1998). Conclusions reached in this review regarding presence or absence of sex differentiation at successive life stages are indicated. Symbols are as in Table 1. 
sources. Quantity and predictability of food influence the costs and benefits of defending feeding territories (Brown 1964). Grant (1997) found feeding territories in $67 \%$ of coral reef fishes, but only $6 \%$ of marine fishes of eastern Canada, and $9 \%$ of freshwater fishes of Canada. Food also influences social structure by influencing abundance and dispersion of potential mates (Emlen and Oring 1977). Differences in mate defence were not as pronounced as those in food defence; $84 \%$ of coral reef fishes defend mates, offspring, or breeding sites, compared to $73 \%$ of marine fishes of eastern Canada, and $68 \%$ of freshwater fishes of Canada (Grant 1997). However, mating on coral reefs may be continual (Thresher 1984), while it is seasonal in freshwater habitats, even most tropical freshwaters (Lowe-McConnell 1975). Whereas short-term mate defence might be common in freshwater, absence of feeding territories may indicate longer term unpredictability of mate distribution and abundance. The size-advantage model requires a reliable estimate of future reproductive potential. As the cost of making a mistake in gonad allocation increases, sex differentiation processes may become increasingly canalized (Francis and Barlow 1993). Ecological stability in coral reef environments may allow more accurate predictions of future mating opportunities necessary for the evolution of sequential hermaphroditism. The absence of sequential hermaphroditism in freshwater habitats is likely because of their unpredictable nature.

\section{Acknowledgements}

Fishclub of the University of Michigan Museum of Zoology Fish Division provided comments on an early draft of the paper. William Fink, Brian Hazlett, Doug Shapiro, Gerald Smith, and two anonymous reviewers provided comments on later drafts.

\section{References}

Abucay, J.S., Mair, G.C., Skibinski, D.O.F. and Beardmore, J.A. (1999) Environmental sex determination: the effect of temperature and salinity on sex ratio in Oreochromis niloticus L. Aquaculture 173, 219-234.

Alberch, P., Gould, S.J., Oster, G.F. and Wake, D.B. (1979) Size and shape in ontogeny and phylogeny. Paleobiology 5, 296-317.

Ali, M., Nicieza, A. and Wootton, R.J. (2003) Compensatory growth in fishes: a response to growth depensation. Fish and Fisheries 4, 147-190.
Allsop, D.J. and West, S.A. (2003) Changing sex at the same relative body size. Nature 425, 783-784.

Aronson, L.R. (1948) Problems in the behaviour and physiology of a species of an African mouthbreeding fish. Transactions of the New York Academy of Sciences 2 , 33-42.

Aronson, L.R. (1951) Factors influencing the spawning frequency in the cichlid fish, Tilapia macrocephala. American Museum Noviates 1484, 1-26.

Atz, J.A. (1964) Intersexuality in fishes. In: Intersexuality (eds C.N. Armstrong and A.J. Marshall). Academic Press, London, pp. 145-232.

Baca Hovey, C., Allen, L.G. and Hovey, T.E. (2002) The reproductive pattern of barred sand bass (Paralabrax nebulifer) from southern California. California Cooperative Oceanic Fisheries Investigations, Reports 43, 174-181.

Baerends, G.P. and Baerends-van Roon, J.M. (1950) An introduction to the study of the ethology of cichlid fishes. Behaviour (Suppl. 1), 235 pp.

Baras, E., Prignon, C., Gohoungo, G. and Mélard, C. (2000) Phenotypic sex differentiation of blue tilapia under constant and fluctuating thermal regimes and its adaptive and evolutionary implications. Journal of Fish Biology 57, 210-223.

Barlow, G.W. (1970) A test of appeasement and arousal hypotheses of courtship behaviour in a cichlid fish, Etroplus maculatus. Zeitschrift für Tierpsychologie 27, 779-806.

Barlow, G.W. (1976) The Midas cichlid in Nicaragua. In: Investigations of the Ichthyofauna of Nicaraguan Lakes (ed. T.B. Thorson). School of Life Sciences, University of Nebraska, Lincoln, Nebraska, pp. 333-358.

Barlow, G.W. (1993) The puzzling paucity of feeding territories among freshwater fishes. Marine Behavior and Physiology 23, 155-174.

Barlow, G.W. (2000) The Cichlid Fishes, Nature's Grand Experiment in Evolution. Perseus Publishing, Cambridge, MA.

Barlow, G.W. (2001) Parsing mouth brooding in cichlid fishes to illuminate the course of evolution. Journal of Aquariculture and Aquatic Sciences, Cichlid Research: State of the Art 9, 66-78.

Baroiller, J., Chourrout, D., Fostier, A. and Jalabert, B. (1995) Temperature and sex chromosomes govern sex ratios of the mouthbrooding cichlid fish Oreochromis niloticus. Journal of Experimental Zoology 273, 216-223.

Baroiller, J.F., Nakayama, I., Foresti, F. and Chourrout, D. (1996) Sex determination studies in two species of teleost fish, Oreochromis niloticus and Leporinus elongatus. Zoological Studies 35, 279-285.

Brown, M.E. (1957) Experimental studies of growth. In: Physiology of Fishes, Vol. 1 (ed. M.E. Brown). Academic Press, New York, pp. 361-400.

Brown, J.L. (1964) The evolution of diversity in avian territorial systems. Wilson Bulletin 76, 160-169. 
Bushman, P.J. and Burns, J.R. (1994) Social control of male maturation in the swordtail characin, Corynopoma riisei. Journal of Fish Biology 44, 263-272.

Buxton, C.D. and Garrett, P.A. (1990) Alternative reproductive styles in seabreams (Pisces: sparidae). Environmental Biology of Fishes 28, 113-124.

Carrasco, L.A.P., Penman, D.J. and Bromage, N. (1999) Evidence for the presence of sex chromosomes in Nile tilapia (Oreochromis niloticus) from synaptonemal complex analysis of $\mathrm{XX}, \mathrm{XY}$, and $\mathrm{YY}$ genotypes. Aquaculture 173, 207-218.

Carrillo, M., Zanuy, S., Blázquez, M., Ramos, J., Piferrer, F. and Donaldson, E.M. (1995) Sex control and ploidy manipulation in sea bass. In: Environmental Impacts of Aquatic Biotechnology. OECD documents, Paris, France, pp. 125-143.

Carruth, L.L. (2000) Freshwater cichlid Crenicara punctulata is a protogynous sequential hermaphrodite. Copeia 2000, 71-82.

Clemens, H.P. and Inslee, T. (1968) The production of unisexual broods by Tilapia mossambica sex reversed with methyltestosterone. Transactions of the American Fisheries Society 97, 18-21.

Conover, D.O. and Heins, S.W. (1987) Adaptive variation in environmental and genetic sex determination in a fish. Science 213, 577-579.

Davis, M.R. and Fernald, R.D. (1990) Social control of neuronal soma size. Journal of Neurobiology 21, 11801188.

Desprez, D. and Melard, C. (1998) Effect of ambient water temperature on sex determinism in the blue tilapia Oreochromis aureus. Aquaculture 162, 79-84.

Devlin, R.H. and Nagahama, Y. (2002) Sex determination and sex differentiation in fish: an overview of genetic, physiological, and environmental influences. Aquaculture 208, 191-364.

Devlin, R.H., McNiel, B.K., Groves, T.D.D. and Donaldson, E.M. (1991) Isolation of a Y-chromosomal DNA probe capable of determining genetic sex in Chinook salmon (Oncorhynchus tshawytscha). Canadian Journal of Fisheries and Aquatic Sciences 48, 1606-1612.

Emlen, S.T. and Oring, L.W. (1977) Ecology, sexual selection, and the evolution of mating systems. Science 197, 215-223.

Faunce, C.H., Patterson, H.M. and Lorenz, J.J. (2002) Age, growth, and mortality of the Mayan cichlid (Cichlasoma urophthalmus) from the southeastern Everglades. Fisheries Bulletin 100, 42-50.

Fernald, R.D. and Hirata, N.R. (1977) Field study of Haplochromis burtoni: quantitative behavioural observations. Animal Behaviour 32, 964-975.

Fink, W.L. (1982) The conceptual relationship between ontogeny and phylogeny. Paleobiology 8, 254-264.

Fishelson, L. (1970) Protogynous sex reversal in the fish Anthias squamipinnis (Teleostei: Anthiidae) regulated by the presence or absence of male fish. Nature 227, 90-91.

Fraley, N.B. and Fernald, R.D. (1982) Social control of developmental rate in the African cichlid, Haplochromis burtoni. Zeitschrift für Tierpsychologie 60, 66-82.

Francis, R.C. (1984) The effects of bidirectional selection for social dominance on agonistic behaviour and sex ratios in the Paradise fish (Macropodus opercularis). Behaviour 90, 25-45.

Francis, R.C. (1990) Temperament in a fish: a longitudinal study of the development of individual differences in aggression and social rank in the Midas cichlid. Ethology 86, 311-325.

Francis, R.C. (1992) Sexual lability in teleosts: developmental factors. The Quarterly Review of Biology 67, 1-18.

Francis, R.C. and Barlow, G.W. (1993) Social control of primary sex differentiation in the Midas cichlid. Proceedings of the National Academy of Science of the United States of America 90, 10673-10675.

Fricke, H.W. and Fricke, S. (1977) Monogamy and sex change by aggressive dominance in coral reef fish. Nature 266, 830-832.

Fryer, G. and Iles, T.D. (1972) The Cichlid Fishes of the Great Lakes of Africa: Their Biology and Evolution. Oliver and Boyd, Edinburgh, UK.

George, T. and Pandian, T.J. (1996) Hormonal induction of sex reversal and progeny testing in the zebra cichlid Cichlasoma nigrofasciatum. Journal of Experimental Zoology 275, 374-382.

Ghiselin, M.T. (1969) The evolution of hermaphroditism among animals. Quarterly Review of Biology 44, 189-208.

Godwin, J.R. (1994) Histological aspects of protandrous sex change in the anemonefish Amphiprion melanopus. Journal of Zoology (London) 232, 199-213.

Godwin, J., Crews, D. and Warner, R.R. (1996) Behavioural sex change in the absence of gonads in a coral reef fish. Proceedings of the Royal Society of London B $\mathbf{2 6 3}$, 1683-1688.

Goodwin, N.B., Balshine, S. and Reynolds, J.D. (1998) Evolutionary trends in parental care in cichlid fish. Proceedings of the Royal Society of London B 265, 22652272.

Gould, S.J. (1977) Ontogeny and Phylogeny. Harvard University Press, Cambridge, MA.

Grant, J.W.A. (1997) Territoriality. In: Behavioural Ecology of Teleost Fishes (ed. J.-G.J. Godin ), Oxford University Press, Oxford, pp. 81-103.

Greenberg, B. (1961) Spawning and parental behaviour in female pairs of the jewelfish, Hemichromis bimaculatus, Gill. Behaviour 18, 44-61.

Griffiths, R., Orr, K.J., Adam, A. and Barber, I. (2000) DNA sex identification in the three-spined stickleback. Journal of Fish Biology 57, 1331-1334.

Guerrero, R.D. (1975) Use of androgens for the production of all-male Tilapia aurea (Steindachner). Transactions of the American Fisheries Society 104, 342-348. 
Guerrero, R.D. and Shelton, W.L. (1974) An acetocarmine squash method for sexing juvenile fish. Progressive Fish Culturist 36, 56.

Hackmann, E. and Reinboth, R. (1974) Delimitation of the critical stage of hormone-influenced sex differentiation in Hemihaplochromis multicolor (Hilgendorf) (Cichlidae). General and Comparative Endocrinology 22, 42-53.

Harnish, C. (2004) Sex Allocation and Social Behaviour of Tramitichromis intermedius (Pisces: Cichlidae). Masters thesis, Boston University, Boston, MA, 54 pp.

Heiligenberg, W. (1965) Color polymorphism in the males of an African cichlid fish. Journal of Zoology (London) 146, 95-97.

Hickling, C.F. (1960) The Malacca Tilapia hybrids. Journal of Genetics 57, 1-10.

Hunter, G.A. and Donaldson, E.M. (1983) Hormonal sex control and its application to fish culture. In: Fish Physiology, Vol. 9B (eds W.S. Hoar, D.J. Randall and E.M. Donaldson). Academic Press, London, pp. 223-303.

Itzkowitz, M., Santangelo, N. and Richter, M. (2001) Parental division of labour and the shift from minimal to maximal role specializations: an examination using a biparental fish. Animal Behaviour 61, 1237-1245.

Jalabert, B., Moreau, J., Planquette, P. and Billard, R. (1974) Déterminismedu du sexe chez Tilapia macrochir et Tilapia nilotica: action de la méthyltestostérone dans l'alimentation des alevins sur la différenciation sexuelle; proportion des sexes dans la descendance des mâles inversés. Annales de Biologie Animale Biochimie et Biophysique 14, 729-739.

Kallman, K.D. (1984) A new look at sex determination in poeciliid fishes. In: Evolutionary Genetics of Fishes (ed. B.J. Turner). Plenum Press, New York, NY, pp. 95-172.

Kolluru, G.R. and Reznick, D.N. (1996) Genetic and social control of male maturation in Phallichthys quadripunctatus (Pisces: Poeciliidae). Journal of Evolutionary Biology 9, 695-715.

Kornfield, I. (1984) Descriptive genetics of cichlid fishes. In: Evolutionary Genetics of Fishes (ed. B.J. Turner). Plenum Press, New York, pp. 591-616.

Langston, R.C. (2004) Gonad Morphology and Sex Change in Sandburrowers (Teleostei: Creediidae). PhD Dissertation, University of Hawaii, Manoa, 138 pp.

Lee, B.Y., Penman, D.J. and Kocher, T.D. (2003) Identification of a sex-determining region in Nile tilapia (Oreochromis niloticus) using bulked segregant analysis. Animal Genetics 34, 1-5.

Liu, Z., Moore, P.H., Ma, H. et al. (2004) A primitive Y chromosome in papaya marks incipient sex chromosome evolution. Nature 427, 348-352.

Loir, M., Canty, C. and LeBail, P.-Y. (1989) Ambisexuality in a South American cichlid: Satanoperca aff leucosticta. Aquatic Living Resources 2, 185-187.

Lowe-McConnell, R.H. (1975) Fish Communities in Tropical Freshwaters: Their Distribution, Ecology, and Evolution. Longman, London, 337 pp.
Marchand, O., Govoroun, M., D'Cotta, H. et al. (2002) DMRT1 expression during gonadal differentiation and spermatogenesis in the rainbow trout, Oncorhynchus mykiss. Biochimica et Biophysica Acta 1493, 180-187.

Matsuda, M., Nagahama, Y., Shinomiya, A. et al. (2002) DMY is a Y-specific DM-domain gene required for male development in the medaka fish. Nature 417, 559-563.

McKaye, K.R. (1977) Defense of a predator's young by a herbivorous fish: an unusual strategy. American Naturalist 111, 301-315.

Meijide, F.J., Nostro, F.L.L. and Guerrero, G.A. (2005) Gonadal development and sex differentiation in the cichild fish Gichlavome dimerus (Teleostei, perciformes): a light- and electron-microscopic study. Journal of Morphology 264, 191-210.

Naish, K.A. and Ribbink, A.J. (1990) A preliminary investigation of sex change in Pseudotropheus lombardoi (Pisces: Cichlidae). Environmental Biology of Fishes 28, 285-294.

Nakamura, M., Kobayashi, T., Chang, X.T. and Nagahama, Y. (1998) Gonadal sex differentiation in teleost fish. Journal of Experimental Zoology 281, 362-372.

Nakashima, Y., Sakai, Y., Karino, K. and Kuwamura, T. (2000) Female-female spawning and sex change in a haremic coral-reef fish, Labroides dimidiatus. Zoological Science 17, 967-970.

Nanda, I., Kondo, M., Hornung, U. et al. (2002) A duplicated copy of DMRT1 in the sex determining region of the Y chromosome of the medaka, Oryzias latipes. Proceedings of the National Academy of Science 99, 11778-11783.

Ohm, D. (1978) Sexualdimorphismus, Polygamie und Geschlechtswechsel bei Crenicara punctulata Gunther 1863 (Cichlidae, Teleostei). Sitzungs-berichte der Gesellschaft für Naturforschender Fruende zu Berlin 18, 90-104.

Ohm, D. (1980) Weibchen werden zu Maenchen: Geschlechtswechsel beim Buntbarsh Crenicara punctulata. Aqurien Magazin 14, 631-634.

Oliveira, R.F. and Canario, A.V.M. (2001) Hormones and social behaviour in cichlid fishes: a case study in the Mozambique tilapia. Journal of Aquariculture and Aquatic Sciences, Cichlid Research: State of the Art 9, 187-207.

Pandian, T.J. and Koteeswaran, R. (1999) Lability of sex differentiation in fish. Current Science 76, 580-583.

Peters, H.M. (1975) Hermaphroditism in cichlid fishes. In: Intersexuality in the Animal Kingdom (ed. R. Reinboth). Springer-Verlag, New York, pp. 228-235.

Polder, J.J.W. (1971) On gonads and reproductive behaviour in the cichlid fish Aequidens portalegrensis (Hensel). Netherlands Journal of Zoology 21, 265-365.

Reilly, S.M., Wiley, E.O. and Meinhardt, D.J. (1997) An integrative approach to heterochrony: the distinction between interspecific and intraspecific phenomena. Biological Journal of the Linnean Society 60, 119-143.

Robertson, D.R. and Warner, R.R. 1978. Sexual patterns in the Labroid fishes of the Western Caribbean, II: the 
parrotfishes (Scaridae). Smithsonian Contributions to Zoology 255, 1-26.

Robertson, D.R. (1972) Social control of sex reversal in a coral reef fish. Science 171, 1007-1009.

Römer, U. and Beisenherz, W. (1996) Environmental determination of sex in Apistogramma (Cichlidae) and two other freshwater fishes (Teleostei). Journal of Fish Biology 48, 714-725.

Ross, R.M. (1987) Sex-change linked growth acceleration in a coral-reef fish, Thalassoma duperrey. Journal of Experimental Zoology 244, 455-461.

Ross, R.M., Losey, G.S. and Diamond, M. (1983) Sex change in a coral reef fish: dependence of stimulation and inhibition of relative size. Science 221, 574-575.

Rubin, D.A. (1985) Effect of $\mathrm{pH}$ on sex ratio in cichlids and a poeciliid (Teleostei). Copeia 1985, 233-235.

Sadovy, Y. and Shapiro, D.Y. (1987) Criteria for the diagnosis of hermaphroditism in fishes. Copeia 1987, 136-156.

Seitz, A. (1942) Die Paarbildung bei einigen Cichliden II. Die Paarbildung bei Hemichromis bimaculatus (Gill). Zeitschrift für Tierpsychologie 5, 74-101.

Shapiro, D.Y. (1979) Social behaviour, group structure, and the control of sex reversal in hermaphroditic fish. In: Advances in the Study of Behaviour, Vol. 10 (eds J.S. Rosenblatt, R.A. Hinde, C. Beer and M.-C. Busnel). Academic Press, New York, pp. 43-102.

Shapiro, D.Y. (1987) Differentiation and evolution of sex change in fishes. Bioscience 37, 490-497.

Shapiro, D.Y. (1992) Plasticity of gonadal development and protandry in fishes. Journal of Experimental Zoology 261, 194-203.

Shapiro, D.Y. and Rasotto, M.B. (1993) Sex differentiation and gonadal development in the diandric, protogynous wrasse, Thalassoma bifasciatum (Pisces, Labridae). Journal of Zoology 230, 231-245.

Smith, C.L. (1975) The evolution of hermaphroditism in fishes. In: Intersexuality in the Animal Kingdom (ed. R. Reinboth). Springer-Verlag, Berlin, pp. 295-310.

Smith, C.L. and Young, P.H. (1966) Gonad structure and the reproductive cycle of the kelp bass, Paralabrax clathratus (Girard), with comments on the relationships of the serranid genus Paralabrax. California Fish and Game 52, 283-292.

Sparks, J.S. and Smith, W.L. (2004) Phylogeny and biogeography of cichlid fishes (Teleostei: Perciformes: Cichlidae). Cladistics 20, 501-517.

Stiassny, M.J.L. and Jensen, J.S. (1987) Labroid intrarelationships revisited: morphological complexity, key inno- vations, and study of comparative diversity. Bulletin of the Museum of Comparative Zoology 151, 269-319.

Streelman, J.T. and Karl, S.A. (1997) Reconstructing labroid evolution with single-copy nuclear DNA. Proceedings of the Royal Society of London B $\mathbf{2 6 4}$, 1011-1020.

Taborski, M. (1984) Broodcare helpers in Lamprologus brichardi: their costs and benefits. Animal Behaviour 32 , 1236-1252.

Thompson, K.W. (1976) Some Aspects of Chromosomal Evolution of the Cichlidae (Teleostei: Perciformes) with Emphasis on Neotropical Forms. PhD thesis, University of Texas, Austin, TX, 132 pp.

Thresher, R.E. (1984) Reproduction in Reef Fishes. T.F.H. Publications, Neptune City, NJ. 399 pp.

Uchida, D., Yamashita, M., Kitano, T. and Iguchi, T. (2002) Oocyte apoptosis during the transition from ovary-like tissue to testes during sex differentiation of juvenile zebrafish. Journal of Experimental Biology 205 , 711-718.

Wang, L.H. and Tsai, C.L. (2000) Effects of temperature on the deformity and sex differentiation of Tilapia, Oreochromis mossambicus. Journal of Experimental Zoology $\mathbf{2 8 6}$, 534-537.

Ward, J.A. and Wyman, R.L. (1977) Ethology and ecology of cichlid fishes of the genus Etroplus in Sri Lanka: preliminary findings. Environmental Biology of Fishes 2, 137-145.

Warner, R.R. (1975) The adaptive significance of sequential hermaphroditism in animals. The American Naturalist 109, 61-82.

Warner, R.R. and Roberson, D.R. 1978. Sexual patterns in the Labroid fishes of the Western Caribbean, I: The wrasses (Labridae). Smithsonian Contributions to Zoology 254, 1-27.

Warner, R.R. and Swearer, S.E. (1991) Social control of sex change in the bluehead wrasse, Thalassoma bifasciatum (Pisces: Labridae). Biological Bulletin 181, 199-204.

Williams, N.J. (1972) On the Ontogeny of Behaviour of the Cichlid Fish Cichlasoma nigrofasciatum (Gunther). PhD Thesis, University of Groningen, The Netherlands, 112 pp.

Zhang, J. (2004) Evolution of DMY, a newly emergent male sex determination gene of medaka fish. Genetics 166, 1887-1895.

Zupanc, G.K.H. (1985) Fish and their Behaviour, How fishes Live: Specially Written for Aquarists. Tetra Press, Melle, Germany. 